\title{
PENGARUH KOMITMEN ORGANISASI, KARAKTERISTIK PEKERJAAN TERHADAP KEPUASAN KERJA KARYAWAN DAN MOTIVASI KERJA SEBAGAI VARIABEL INTERVENING
}

\author{
Dina Prasetyaningrum \\ Departemen Manajemen, Fakultas Ekonomi Universitas Nahdlatul Ulama Al Ghazali Cilacap \\ Cilacap, Indonesia, dinaprasetyaningrum.dp@gmail.com
}

\begin{abstract}
Background - Employee job satisfaction becomes a matter that must be considered for the success and success of the company. There are factors that can affect job satisfaction, namely factors in workers and work factors including organizational commitment, job characteristics, and work motivation.
\end{abstract}

Diterima : 17 Juni 2020

Direview : 18 Juni 2020

Direvisi : 22 Juni 2020

Disetujui : 24 Juli 2020

Aim - This study aims to determine and analyze partially and simultaneously the effect of organizational commitment, job characteristics, and work motivation on job satisfaction of employees of PT. Pertamina RU IV (Persero) Cilacap.

Design / methodology / approach - The research method uses quantitative by using path analysis techniques (Path Analysis). Samples were taken by purposive sampling technique with a total sample of 123 people, which included Maintenance Execution employees of PT. Pertamina RU IV (Persero) Cilacap.

Findings - The results of the study indicate that job satisfaction is positively and significantly affected by organizational commitment through intervening variables of work motivation; job characteristics; and work motivation.

Research implication - The results of the study can be used as a company reference in paying attention to organizational commitment, job characteristics, work motivation, and job satisfaction to achieve organizational goals that are effective and efficient.

Limitations - Limitations of this study on the number of variables used to predict job satisfaction are limited simultaneously at $66.4 \%$, so that it can use other variables that can provide a greater influence on job satisfaction.

Keyword : organizational commitment, characteristics, work motivation, satisfaction

\begin{abstract}
ABSTRAK
Latar belakang - Kepuasan kerja karyawan menjadi hal yang perlu diperhatikan guna keberhasilan dan kesuksesan perusahaan. Terdapat faktor yang dapat mempengaruhi kepuasan kerja yaitu faktor pada diri pekerja dan faktor pekerjaan diantaranya komitmen organisasi, karakteristik pekerjaan, dan motivasi kerja.

Tujuan - Penelitian ini bertujuan untuk mengetahui dan menganalisis secara parsial dan simultan pengaruh komitmen organisasi, karakteristik pekerjaan, dan motivasi kerja terhadap kepuasan kerja karyawan PT. Pertamina RU IV (Persero) Cilacap.

Desain / metodologi / pendekatan - Metode penelitian menggunakan kuantitatif dengan menggunakan teknik analisis jalur (Path Analysis). Sampel diambil dengan teknik purposive sampling dengan jumlah sampel sebesar 123 orang, yang meliputi karyawan Maintenance Execution PT. Pertamina RU IV (Persero) Cilacap.

Temuan - Hasil dari penelitian menunjukan bahwa kepuasan kerja dipengaruhi positif dan signifikan oleh komitmen organisasi melalui variabel intervening motivasi kerja; karakteristik pekerjaan; dan motivasi kerja.
\end{abstract}


Implikasi penelitian - Hasil penelitian dapat dijadikan referensi perusahaan dalam memperhatikan komitmen organisasi, karakteristik pekerjaan, motivasi kerja, dan kepuasan kerja untuk mencapai tujuan organisasi yang efektif dan efisien.

Batasan penelitian - Keterbatasan dari penelitian ini pada jumlah variabel yang digunakan untuk memprediksi kepuasan kerja yang terbatas secara simultan sebesar 66,4\%, sehingga dapat menggunakan variabel-variabel lainnya yang dapat memberikan pengaruh lebih besar terhadap kepuasan kerja.

Kata kunci : komitmen organisasi, karakteristik, motivasi kerja, kepuasan

\section{PENDAHULUAN}

Sumber Daya Manusia (SDM) adalah salah satu hal dan aset yang sangat penting guna mencapai keberhasilan dan kesuksesan di dalam suatu perusahaan yang sangat ditentukan oleh kinerja dan kualitas dari SDM yang mendukung kegiatan operasional perusahaan. PT. Pertamina RU IV (Persero) Cilacap secara konsisten melakukan program perekrutan, pembinaan, penilaian kinerja dan pengembangan Sumber Daya Manusia (SDM) guna meningkatkan produktivas kerja untuk perusahaan, serta umpan balik untuk pekerja dengan meningkatkan kepuasan kerja dengan adanya data annual report (laporan tahunan pekerja) sehingga dapat tercapai visi dan misi sesuai dengan tujuan perusahaan yang efektif dan efisien.

Berdasarkan penjelasan hal diatas, maka kepuasan kerja karyawan menjadi hal yang perlu diperhatikan guna keberhasilan dan kesuksesan perusahaan. Menurut Wijono (2010), kepuasan kerja adalah kondisi psikis individu yang menyenangkan, yang dirasakan oleh pekerja atas peranannya di dalam perusahaan dan pemenuhan kebutuhannya terpenuhi dengan baik dan nilai-nilai yang penting bagi diri pekerja.

Menurut Juliansyah (2013), terdapat faktor yang dapat mempengaruhi kepuasan kerja diantaranya yaitu faktor pada diri pekerja dan faktor pekerjaan. Kepuasan atau ketidakpuasan karyawan dapat menyebabkan perilaku yang mempengaruhi fungsi dan komitmen organisasi (Spector, 2010). Menurut Robbins dan Judge (2013), kepuasan kerja memiliki perasaan yang positif tentang pekerjaan. Kepuasan kerja hal yang sangat penting dalam mengetahui perilaku organisasi pekerja karena dengan tingkat tinggi kepuasan kerja memegang perasaan positif dan motivasi kerja yang tinggi tentang pekerjaanya. Hal ini menunjukkan bahwa kepuasan kerja berkaitan dengan karakteristik pekerjaan dan motivasi kerja.

Berdasarkan kondisi di PT. Pertamina RU IV (Persero) Cilacap, maka variabel yang memungkinkan mempengaruhi kepuasan kerja adalah komitmen organisasi (faktor diri pekerja), karakteristik pekerjaan (faktor pekerjaan), dan motivasi kerja (faktor diri pekerja). 
Terdapat beberapa upaya dan kegiatan yang dilakukan PT. Pertamina RU IV (Persero) Cilacap untuk meningkatkan komitmen organisasi dan keterlibatan pekerja guna perbaikan kualitas kerja Sumber Daya Manusia (SDM) dengan tujuan mewujudkan sebagai perusahaan migas nasional berkelas dunia. Di antaranya yaitu melaksanakan program Pertamina Quality Award (PQA), Continuous Improvement Program (CIP) dan Knowledge Management Pertamina (KOMET). Program-program tersebut dilaksanakan sebagai upaya untuk meningkatkan komitmen organisasi dan keterlibatan pekerja di setiap kegiatan dalam tujuan peningkatan kinerja dan kepuasan kerja di perusahaan. Hal itu dilakukan agar tercapai visi misi PT. Pertamina RU IV (Persero) Cilacap menjadi perusahaan minyak nasional kelas dunia yang mampu bersaing dalam era global.

Komitmen organisasi adalah sampai tingkat mana seorang karyawan memihak pada suatu organisasi tertentu dan berniat memelihara keanggotaan pada organisasi tersebut (Robbins \& Judge, 2013). Model komitmen organisasi menurut Allen \& Meyer (2013) dibagi menjadi tiga komponen yaitu komitmen afektif, komitmen berkelanjutan, dan komitmen normatif. Komitmen Afektif (Affective Commitment) adalah perasaan emosional untuk organisasi dan keyakinan dalam nilai-nilainya. Komitmen berkelanjutan (Continuance Commitment) adalah nilai ekonomi yang dirasa dari bertahan dalam suatu organisasi bila dibandingkan dengan meninggalkan organisasi tersebut. Komitmen normatif (Normative Commitment) adalah kewajiban untuk bertahan dalam organisasi untuk alasan-alasan moral atau etis.

Sebagian besar penelitian menunjukkan bahwa komitmen organisasi memiliki hubungan yang signifikan dan positif dengan kepuasan kerja, diantaranya yaitu penelitian yang dilakukan oleh Yucel (2012) juga menunjukkan hasil bahwa kepuasan kerja memberikan hubungan yang positif dengan komitmen organisasi.

Karakteristik pekerjaan merupakan rancangan kegiatan kerja karyawan yang disusun berdasarkan kemampuan dan keinginan karyawan tersebut, di mana karyawan bekerja tidak hanya untuk memenuhi kebutuhannya tetapi juga bertujuan untuk menambah kepuasan kerja dengan pekerjaan yang tepat dan mengetahui kinerjanya dari umpan balik dari perusahaan sebagai hasil yang diberikannya kepada perusahaan. Model karakteristik pekerjaan yang digunakan adalah model Hackman \& Oldham (2010) dikenal dengan istilah teori karakteristik pekerjaan (job characteristic theory). Model karakteristik pekerjaan merupakan suatu pendekatan terhadap pemerkaya pekerjaan (job enrichment) yang dispesifikasikan ke dalam lima dimensi karakteristik inti yaitu keragaman keterampilan (skill variety), jati diri dari tugas (task identity), signifikansi 
tugas (task significance), otonomi (autonomy) dan umpan balik (feed back).

Menurut Hackman \& Oldham (2010) yang menyebutkan bahwa karakteristik pekerjaan akan memberikan nilai lebih pada pekerjaan tersebut yang dapat menghasilkan karyawan dengan motivasi kerja yang tinggi dan merasa puas untuk menggunakan tenaga dan usahanya dalam bekerja sehingga terbentuklah kepuasan kerja karyawan di dalam perusahaan.

\section{TINJAUAN PUSTAKA}

Menurut Gibson (2012), kepuasan kerja merupakan bentuk atau sikap emosional, ekspresi dan perasaan seseorang dari proses dan sistem pekerjaannya. Menurut Wijono (2010), kepuasan kerja merupakan suatu hal perasaan yang positif dari seseorang dalam menyelesaikan tanggungjawab dan tugas untuk memenuhi kebutuhan dan nilai yang positif bagi individu.

Berdasarkan pendapat beberapa ahli di atas mengenai faktor-faktor yang mempengaruhi ada tidaknya kepuasan kerja karyawan, maka peneliti menyimpulkan beberapa hal yang dapat dijadikan indikator dalam mengukur tingkat kepuasan karyawan yang selanjutnya dalam penelitian ini akan dijadikan indikator dalam mengukur tingkat kepuasan kerja karyawan, yaitu:

1. Kepuasan karyawan terhadap gaji atau upah.

2. Kepuasan karyawan terhadap tanggungjawab pekerjaannya.

3. Kepuasan karyawan terhadap komunikasi dengan atasan dan teman kerja.

4. Kepuasan karyawan terhadap fasilitas dan benefit.

5. Kepuasan karyawan terhadap kenaikkan golongan atau promosi jabatan.

6. Kepuasan karyawan terhadap kondisi dan keamanan kerja.

Penelitian yang dilakukan oleh Yucel (2012) yang berjudul "Examining the Relationships among Job Satisfaction, Organizational Commitment, and Turnover Intention: An Empirical Study" menunjukkan hasil bahwa kepuasan kerja memberikan hubungan yang positif dan signifikan dengan komitmen organisasi.

Komitmen organisasi adalah sejauh mana setiap individu karyawan tetap berada pada perusahaan dan organisasi yang mempunyai tujuan dan berniat untuk memelihara keanggotaan pekerja dalam perusahaan dan organisasi tersebut (Robbins \& Judge, 2013). Luthans (2011) dalam bukunya Organizational Behavior mendefinisikan komitmen organisasi sebagai tindakan dan sikap, yaitu:

1. Keinginan kuat untuk tetap sebagai pekerja dan keanggotaan pada organisasi.

2. Keinginan untuk mengikuti sesuai tujuan dan keinginan suatu organisasi. 
3. Keyakinan penerimaan nilai dan tujuan suatu organisasi.

Komitmen organisasi (organizational commitment) merupakan suatu keadaan di mana masing-masing individu sebagai pekerja menyesuaikan diri terhadap tujuan suatu organisasi dan memiliki keinginan untuk tetap berada dalam keanggotaannya dalam organisasi tersebut "Organizational Commitmentis the degree to which employees believe in and accept organizational goals and desire to remain with the organization" (Mathis \& Jackson, 2011).

Berdasarkan teori-teori tersebut dapat dinyatakan komitmen organisasi merupakan tindakan dan sikap yang dimiliki pekerja untuk tetap loyal dan bertanggungjawab terhadap perusahaan. Bersedia untuk tetap bekerja dalam melaksanakan tugas dengan sebaiksebaiknya demi tercapainya tujuan dan keinginan suatu perusahaan.

Menurut Steers (2011) terdapat tiga faktor yang dapat mempengaruhi ada tidaknya komitmen organisasi pada perusahaan, yaitu:

1. Faktor personal (individu) yang meliputi kepuasan kerja (job satisfaction), psychological contract, job choice factors, dan karakteristik personal. Faktorfaktor tersebut yang akan membentuk komitmen awal.

2. Faktor organisasi, meliputi initial works experiences, job scope, supervisi (supervision), goal consistency organizational. Semua faktor ini akan membentuk sikap bertanggung jawab terhadap perusahaan dan organisasi.

3. Non-organizational factors, yang meliputi availability of alternative job. Faktor tersebut bukan berasal dari dalam perusahaan dan organisasi, misal mengenai ada tidak nya pilihan untuk pekerjaan lain.

Menurut Robbins \& Judge (2013), karakteristik pekerjaan merupakan salah satu faktor yang dapat mempengaruhi kepuasan kerja karyawan, model karakteristik pekerjaan (job characteristics models) dideskripsikan dalam lima dimensi pekerjaan utama, yaitu :

1. Keanekaragaman keterampilan (skill variety). Banyaknya ketrampilan yang diperlukan untuk melakukan pekerjaan.

2. Identitas tugas (identity task). Melihat hasil kinerja dengan cara mengetahui sejauh mana penyelesaian pekerjaan secara keseluruhan.

3. Arti tugas (task significance). Mengukur sejauh mana pekerjaan mempunyai dampak yang positif yang dirasa penting untuk tugas oleh pekerja maka cenderung memiliki kepuasan kerja.

4. Otonomi (autonomy). Tingkat kebebasan pemegang kerja, mempunyai peluang mengambil keputusan dan keleluasaan yang diperlukan untuk menjadwalkan pekerjaan dan memutuskan prosedur tepat untuk menyelesaikannya dengan 
baik sehingga akan menimbulkan kepuasan kerja bagi para pekerja.

5. Umpan balik (feedback). Tingkat dimana pelaksanaan aktivitas kerja dalam memperoleh informasi tentang keefektifan kegiatannya. Hal ini pada pekerjaan dapat meningkatkan tingkat kepuasan kerja pekerja.

Model karakteristik pekerjaan yang digunakan adalah model Hackman \& Oldham (2010) yang telah mengalami penyempurnaan dari model sebelumnya. Motivasi kerja secara internal yang tinggi, kepuasan kerja yang tinggi, dan tingkat kemangkiran yang rendah dapat dipengaruhi dan dihubungkan dengan dimensi karakteristik pekerjaan di perusahaan tersebut.

Penelitian yang dilakukan oleh Franciscus (2013) dan Ahmad \& Taghrid (2015) memberikan hasil bahwa karakteristik pekerjaan memiliki pengaruh positif yang signifikan terhadap kepuasan kerja pada karyawan. Penelitian Thomas Adrian et al., (2004) yang berjudul "Job Characteristics and Personality as Predictors of Job Satisfaction", hasil penelitian menunjukkan bahwa karakteristik pekerjaan berpengaruh positif secara signifikan terhadap kepuasan kerja.

Motivasi kerja merupakan sikap dan tindakan masing-masing individu terhadap pekerjaannya yang bisa mempengaruhi kepuasan kerja bagi pekerja (Robbins \&
Judge, 2013). Motivasi kerja diusahakan bagi masing-masing individu untuk dapat menggabungkan dirinya dengan organisasi untuk turut berperan dengan baik (Anoraga, 2010). Dapat disimpulkan bahwa motivasi kerja merupakan tenaga pendorong atau daya kekuatan untuk melakukan suatu usaha yang diarahkan pada perilaku yang melibatkan diri dengan pekerjaan pada perusahaan tersebut.

Penelitian ini disusun berdasarkan hubungan antara komitmen organisasi, karakteristik pekerjaan, dan motivasi kerja sebagai variabel intervening terhadap kepuasan kerja karyawan PT. Pertamina RU IV (Persero) Cilacap, dimana dengan meningkatnya komitmen organisasi, karakteristik pekerjaan, dan motivasi kerja akan mempengaruhi dan meningkatkan kepuasan kerja karyawan. Hipotesis disusun berdasarkan kajian yang telah diuraikan sebelumnya sehingga dapat dirumuskan sebagai berikut:

\section{H1:Komitmen organisasi berpengaruh} signifikan terhadap kepuasan kerja.

H2:Karakteristik pekerjaan berpengaruh signifikan terhadap kepuasan kerja.

H3:Komitmen organisasi berpengaruh signifikan terhadap motivasi kerja.

H4:Karakteristik pekerjaan berpengaruh signifikan terhadap motivasi kerja.

H5:Motivasi kerja berpengaruh signifikan terhadap kepuasan kerja. 


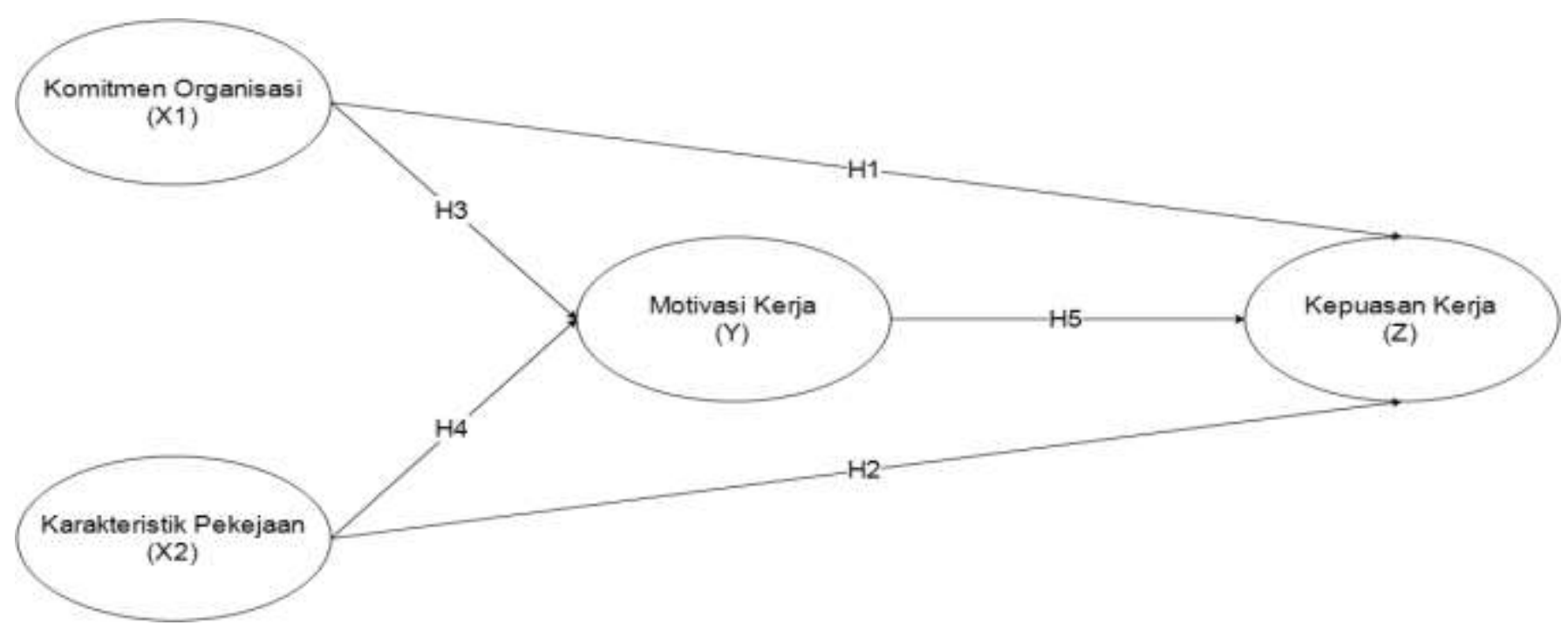

Gambar 1. Kerangka Penelitian

\section{METODOLOGI PENELITIAN}

Penelitian ini dilakukan di PT. Pertamina RU IV (Persero) Cilacap. Penelitian ini meliputi komitmen organisasi, karakteristik pekerjaan, motivasi kerja, dan kepuasan kerja karyawan di PT. Pertamina RU IV (Persero) Cilacap.

Metode penelitian menggunakan kuantitatif dengan menggunakan perhitungan statistik sebagai dasar analisis. Sampel diambil dengan teknik pengambilan purposive sampling karena dengan melihat ciri-ciri yang menjadi karakteristik pekerjaan dalam variabel dengan jumlah sampel sebesar 123 orang, yang meliputi karyawan Maintenance Execution PT. Pertamina RU IV (Persero) Cilacap.

Penelitian menggunakan rentang penilaian dengan menggunakan skala likert dimana digunakan nilai 1-5, dimana nilai 1 menunjukkan penilaian sangat tidak setuju
(STS), 2 menunjukkan tidak setuju (ST), 3 dikategorikan cukup setuju (CS), 4 dikategorikan setuju (S), 5 dikategorikan sangat setuju (SS). Skala likert digunakan untuk mengukur sikap, pendapat, dan persepsi seseorang atau sekelompok orang tentang fenomena sosial (Sugiyono, 2018).

Penelitian ini mempergunakan komitmen organisasi (X1) dan karakteristik pekerjaan (X2) sebagai variabel independent yaitu variabel bebas tidak dipengaruhi oleh variabel lain. Motivasi kerja (Y) sebagai variabel mediasi sedangkan kepuasan kerja (Z) sebagai variabel dependent yaitu variabel terikat dipengaruhi oleh variabel lainnya.

Komitmen organisasi diukur dengan menggunakan kuesioner yang mengacu pada Allen \& Meyer (2013) yaitu komitmen afektif, komitmen berkelanjutan, dan komitmen normatif. Komitmen karyawan 
terhadap organisasi diukur dengan indikator:

1. Karyawan punya keinginan kuat untuk tetap sebagai anggota organisasi.

2. Karyawan punya keinginan untuk berusaha keras sesuai keinginan organisasi.

3. Karyawan memiliki keyakinan tertentu, dan penerimaan nilai dan tujuan organisasi.

Karakteristik pekerjaan mengacu pada Hackman \& Oldham (2010) yang memiliki dimensi skill variety, task identity, autonomy, task significance, dan feedback dapat diukur dengan indikator :

1. Karyawan memiliki banyak keterampilan yang diperlukan untuk melakukan pekerjaan.

2. Karyawan berpikir bahwa pekerjaan yang dilakukannya adalah pekerjaan yang penting.

3. Karyawan memiliki posisi yang jelas sesuai dengan levelnya.

4. Karyawan memiliki otonomi pada masing-masing posisinya.

5. Karyawan mendapatkan feedback berupa saran dan kritik membangun.

Motivasi kerja menurut Munandar (2014) menggunakan dimensi valence, expectancy, instrumentality dapat diukur dengan indikator:

1. Karyawan memiliki keyakinan untuk memperoleh prestasi.
2. Karyawan memiliki kayakinan memperoleh promosi jabatan didasarkan atas prestasi.

3. Karyawan memiliki tanggung jawab yang kuat dalam melaksanakan tugas.

4. Karyawan selalu berusaha memenuhi kebutuhan hidup dan kebutuhan kerjanya.

Metode analisis data dalam studi ini menggunakan teknik analisis jalur (Path Analysis), sebelumnya data diuji dengan uji instrument (validitas dan reliabilitas), uji asumsi klasik, dan uji hipotesis. Analisis jalur merupakan suatu metode penelitian yang utamanya digunakan untuk menguji kekuatan hubungan langsung dan tidak langsung diantara berbagai variabel (Ghozali, 2016). Analisis jalur menggunakan diagram jalur untuk merepresentasikan permasalahan dalam bentuk gambar dan menentukan persamaan struktural yang menyatakan hubungan antar variabel pada diagram jalur tersebut. Diagram jalur dapat digunakan untuk menghitung pengaruh langsung dan tidak langsung dari variabel eksogen terhadap suatu variabel endogen.

\section{HASIL DAN PEMBAHASAN}

Penelitian ini bertujuan untuk mengetahui hubungan antara komitmen organisasi, karakteristik pekerjaan, motivasi kerja dan kepuasan kerja karyawan di PT. Pertamina RU IV (Persero) Cilacap. Instrumen penelitian tersebut terlebih dahulu diuji validitas dan reliabilitasnya dengan 
menggunakan analisis korelasi Pearson Product Moment dan Cronbachs Alpha mendapatkan instrumen yang benar-benar valid dan reliabel dalam mengukur variabel penelitian. Analisis regresi tersebut akan dilakukan sebanyak dua kali, karena adanya dua diagram jalur yang akan dianalisis, yaitu diagram jalur digunakan untuk mengetahui pengaruh komitmen organisasi dan karakteristik pekerjaan terhadap motivasi kerja dan diagram jalur untuk mengetahui pengaruh komitmen organisasi, karakteristik pekerjaan dan motivasi kerja terhadap kepuasan kerja. Setelah seluruh asumsi klasik (normalitas, multikolinearitas, dan heteroskedastisitas) dalam analisis regresi berganda terpenuhi pada tahap I, tahap analisis selanjutnya adalah tahap inti dari analisis regresi. Berikut hasil analisis regresi tahap I:

Tabel 1.

Hasil Analisis Regresi Tahap I

\begin{tabular}{l|c|r|r}
\multicolumn{1}{c|}{ Variabel } & Coefficient Beta $(\beta)$ & $t_{\text {hitung }}$ & Sig. \\
\hline Komitmen Organisasi & 0,396 & 4,913 & 0,000 \\
Karakteristik Pekerjaan & 0,279 & 3,461 & 0,001 \\
\hline Sumber: Data Primer Diolah, 2019 & &
\end{tabular}

Berdasarkan Tabel 1. diperoleh beberapa hasil sebagai berikut:

1. Nilai signifikan variabel komitmen organisasi (X1) adalah sebesar 0,000 dengan nilai thitung bertanda positif sebesar 4,913. Hasil tersebut menunjukkan nilai signifikan lebih kecil dari 0,05 dan nilai thitung bertanda positif lebih besar dari nilai $t_{\text {tabel }}$ menunjukkan bahwa variabel komitmen organisasi (X1) berpengaruh positif dan signifikan terhadap variabel motivasi kerja (Y). Semakin tinggi komitmen organisasi karyawan maka semakin tinggi motivasi kerjanya.

2. Nilai signifikan variabel karakteristik pekerjaan (X2) adalah sebesar 0,001 dengan nilai thitung bertanda positif sebesar 3,461. Hasil tersebut
3. menunjukkan nilai signifikan lebih kecil dari 0,05 dan nilai thitung bertanda positif lebih besar dari nilai $t_{\text {tabel }}$ menunjukkan bahwa variabel karakteristik pekerjaan berpengaruh positif dan signifikan terhadap variabel motivasi kerja (Y). Semakin tinggi karakteristik pekerjaan, maka semakin tinggi motivasi kerja karyawan di PT. Pertamina RU IV (Persero) Cilacap.

Setelah seluruh asumsi klasik (normalitas, multikolinearitas, dan heteroskedastisitas) dalam analisis regresi berganda terpenuhi pada tahap II, tahap analisis selanjutnya adalah tahap inti dari analisis regresi. Berikut hasil analisis regresi tahap II. 
Tabel 2.

Hasil Analisis Regresi Tahap II

\begin{tabular}{l|c|r|r}
\multicolumn{1}{c}{ Variabel } & Coefficient Beta $(\beta)$ & \multicolumn{1}{c}{ thitung } & Sig. \\
Komitmen Organisasi & 0,078 & 1,252 & 0,213 \\
Karakteristik Pekerjaan & 0,235 & 3,973 & 0,000 \\
Motivasi Kerja & 0,645 & 10,086 & 0,000 \\
\hline
\end{tabular}

Sumber: Data Primer Diolah, 2019

Berdasarkan Tabel 2. diperoleh beberapa hasil sebagai berikut:

1. Nilai signifikan variabel komitmen organisasi (X1) adalah sebesar 0,213 dengan nilai thitung bertanda positif sebesar 1,252. Hasil tersebut menunjukkan nilai signifikan lebih besar dari 0,05 dan nilai thitung bertanda positif lebih kecil dari nilai $t_{\text {tabel }}$ menunjukkan bahwa variabel komitmen organisasi berpengaruh positif namun tidak signifikan terhadap variabel kepuasan kerja. Hasil ini sekaligus menunjukkan bahwa variabel komitmen organisasi tidak mampu berpengaruh secara langsung terhadap variabel kepuasan kerja.

2. Nilai signifikan variabel karakteristik pekerjaan (X2) adalah sebesar 0,000 dengan nilai thitung bertanda positif sebesar 3,973. Hasil tersebut menunjukkan nilai signifikan lebih kecil dari 0,05 dan nilai thitung bertanda positif lebih besar dari nilai $t_{\text {tabel }}$ menunjukkan bahwa variabel karakteristik pekerjaan berpengaruh positif dan signifikan terhadap variabel kepuasan kerja. Semakin tinggi karakteristik pekerjaan, maka semakin tinggi kepuasan kerja karyawan di PT. Pertamina RU IV (Persero) Cilacap. Hasil ini sekaligus menunjukkan bahwa variabel karakteristik pekerjaan dapat berpengaruh secara langsung terhadap kepuasan kerja dengan koefisien jalur sebesar 0,235.

3. Nilai signifikan variabel motivasi kerja (Y) adalah sebesar 0,000 dengan nilai $t_{\text {hitung }}$ bertanda positif sebesar 10,086. Hasil tersebut menunjukkan nilai signifikan lebih kecil dari 0,05 dan nilai $t_{\text {hitung }}$ bertanda positif lebih besar dari nilai $t_{\text {tabel }}$ menunjukkan bahwa variabel motivasi kerja berpengaruh positif dan signifikan terhadap variabel motivasi kerja. Semakin tinggi motivasi kerja, maka semakin tinggi kepuasan kerja karyawan di PT. Pertamina RU IV (Persero) Cilacap. Hasil ini sekaligus menunjukkan bahwa variabel motivasi kerja mampu berpengaruh langsung terhadap variabel kepuasan kerja dengan koefisien jalur sebesar 0,645.

Analisis jalur dalam penelitian ini digunakan untuk mengetahui pengaruh langsung dan tidak langsung variabel komitmen organisasi dan karakteristik pekerjaan terhadap variabel kepuasan kerja 
dengan variabel motivasi kerja sebagai analisis regresi tahap I dan II, diperoleh variabel intervening. Berdasarkan hasil beberapa hasil sebagai berikut di bawah ini.



Gambar 2. Hasil Estimasi Analisis Jalur

Keterangan:

$\mathrm{Ns}=$ koefisien jalur tidak signifikan

** $=$ koefisien jalur signifikan

$$
\begin{aligned}
& Y=0,396 X 1+0,279 X 2 \\
& Z=0,078 X 1+0,235 X 2+0,645 Y
\end{aligned}
$$

.... (model persamaan 1$)$

.... (model persamaan 2$)$

Berdasarkan Gambar 1. Analisis Jalur langsung dan tidak langsung sebagai diperoleh beberapa hasil uji pengaruh berikut di bawah ini.

Tabel 3.

\begin{tabular}{|c|c|c|c|}
\hline Variabel & $\begin{array}{l}\text { Pengaruh } \\
\text { Langsung } \\
\text { (DE) }\end{array}$ & $\begin{array}{l}\text { Pengaruh Tidak } \\
\text { Langsung (IE) melalui } \\
\text { Motivasi kerja }\end{array}$ & Perbandingan \\
\hline $\begin{array}{l}\text { Komitmen } \\
\text { Organisasi }\end{array}$ & $0,078^{\mathrm{ns}}$ & $\begin{array}{l}0,396^{* *} \times 0,645^{* *}= \\
0,255^{* *}\end{array}$ & $\begin{array}{l}\text { DE tidak signifikan, IE signifikan yang berarti } \\
\text { pengaruh sebenarnya adalah secara tidak } \\
\text { langsung melalui motivasi kerja }\end{array}$ \\
\hline $\begin{array}{l}\text { Karakteristik } \\
\text { Pekerjaan }\end{array}$ & $0,235^{* *}$ & $\begin{array}{l}0,279^{* *} \times 0,645^{* *}= \\
0,180^{* *}\end{array}$ & $\begin{array}{l}\text { DE signifikan, IE signifikan, DE > IE yang } \\
\text { berarti pengaruh sebenarnya adalah secara } \\
\text { langsung tanpa dimediasi oleh motivasi kerja }\end{array}$ \\
\hline
\end{tabular}

Hasil Uji Pengaruh Langsung dan Tidak Langsung

Sumber: Data Primer Diolah, 2019

Berdasarkan Tabel 3. di atas, diperoleh beberapa hasil sebagai berikut:

1. Hipotesis 1: Komitmen organisasi berpengaruh signifikan terhadap kepuasan kerja.
Hasil menunjukkan bahwa variabel komitmen organisasi tidak mampu berpengaruh secara langsung terhadap variabel kepuasan kerja. Namun demikian dari hasil uji pengaruh langsung dan tidak langsung, koefisien 
jalur variabel komitmen organisasi terhadap variabel kepuasan kerja melalui motivasi kerja adalah signifikan sebesar 0,255, hal ini berarti variabel komitmen organisasi sebenarnya mampu berpengaruh terhadap kepuasan kerja namun dengan di mediasi oleh motivasi kerja. Hal ini menunjukkan bahwa $\mathrm{H} 1$ diterima.

2. Hipotesis 2: Karakteristik pekerjaan berpengaruh signifikan terhadap kepuasan kerja.

Hasil menunjukkan bahwa variabel karakteristik pekerjaan dapat berpengaruh secara langsung terhadap kepuasan kerja dengan koefisien jalur sebesar 0,235.

Berdasarkan hasil uji pengaruh langsung dan tidak langsung, variabel tersebut juga mampu berpengaruh secara tidak langsung terhadap kepuasan kerja melalui motivasi kerja dengan koefisien jalur yang signifikan sebesar 0,180. Dari hasil analisis tersebut dapat dilihat bahwa pengaruh langsung dan tidak langsung adalah signifikan namun besar pengaruh langsung lebih besar dari pengaruh tidak langsung, maka diperoleh kesimpulan bahwa pengaruh variabel karakteristik pekerjaan sebenarnya berpengaruh langsung terhadap variabel kepuasan kerja tanpa harus di mediasi oleh variabel motivasi kerja. Tingginya karakteristik pekerjaan mampu meningkatkan kepuasan kerja karyawan tanpa harus diikuti tingginya motivasi kerja. Hal ini menunjukkan $\mathrm{H} 2$ diterima.

3. Hipotesis 3: Komitmen organisasi berpengaruh signifikan terhadap motivasi kerja.

Nilai signifikan variabel komitmen organisasi (X1) adalah sebesar 0,000 dengan nilai thitung bertanda positif sebesar 4,913. Hasil tersebut menunjukkan nilai signifikan lebih kecil dari 0,05 dan nilai thitung bertanda positif lebih besar dari nilai $t_{\text {tabel }}$ menunjukkan bahwa variabel komitmen organisasi (X1) berpengaruh positif dan signifikan terhadap variabel motivasi kerja (Y). Semakin tinggi komitmen organisasi karyawan maka semakin tinggi motivasi kerjanya. Hal ini menunjukkan bahwa H3 diterima.

4. Hipotesis 4: Karakteristik pekerjaan berpengaruh signifikan terhadap motivasi kerja.

Nilai signifikan variabel karakteristik pekerjaan (X2) adalah sebesar 0,001 dengan nilai thitung bertanda positif sebesar 3,461. Hasil tersebut menunjukkan nilai signifikan lebih kecil dari 0,05 dan nilai thitung bertanda positif lebih besar dari nilai $t_{\text {tabel }}$ menunjukkan bahwa variabel karakteristik pekerjaan berpengaruh positif dan signifikan terhadap variabel motivasi kerja (Y). Semakin tinggi karakteristik pekerjaan, 
maka semakin tinggi motivasi kerja karyawan di PT. Pertamina RU IV (Persero) Cilacap. Hal ini menunjukkan bahwa $\mathrm{H} 4$ diterima.

5. Hipotesis 5: Motivasi kerja memberikan berpengaruh signifikan terhadap kepuasan kerja.

Nilai signifikan variabel motivasi kerja (Y) adalah sebesar 0,000 dengan nilai $t_{\text {hitung }}$ bertanda positif sebesar 10,086. Hasil tersebut menunjukkan nilai signifikan lebih kecil dari 0,05 dan nilai $t_{\text {hitung }}$ bertanda positif lebih besar dari nilai $t_{\text {tabel }}$ menunjukkan bahwa variabel motivasi kerja berpengaruh positif dan signifikan terhadap variabel kepuasan kerja. Semakin tinggi motivasi kerja, maka semakin tinggi kepuasan kerja karyawan di PT. Pertamina RU IV (Persero) Cilacap. Hal ini menunjukkan bahwa $\mathrm{H} 5$ diterima.

Tabel 4.

Hasil Uji Analisis Regresi Simultan

\begin{tabular}{|c|c|c|c|c|}
\hline $\mathbf{R}$ & $R$ Square & $\begin{array}{l}\text { Adjusted } R \\
\text { Square }\end{array}$ & $\begin{array}{l}\text { Std. Error of } \\
\text { the Estimate }\end{array}$ & $\begin{array}{l}\text { Durbin- } \\
\text { Watson }\end{array}$ \\
\hline 0,815 & 0,664 & 0,656 & 2,62178 & 1,499 \\
\hline
\end{tabular}

Sumber: Data Primer Diolah, 2019

Berdasarkan hasil analisis regresi pengaruh langsung secara simultan sebesar 0,664 yang berarti besar kontribusi yang diberikan variabel komitmen organisasi (X1), karakteristik pekerjaan (X2) dan motivasi kerja (Y) secara simultan berpengaruh signifikan terhadap variabel kepuasan kerja (Z) adalah sebesar 66,4\%, sisanya sebanyak $33,6 \%$ dipengaruhi oleh faktor lain di luar ke tiga variabel tersebut.

\section{KESIMPULAN}

Berdasarkan hasil penelitian, diperoleh beberapa kesimpulan sebagai berikut:

1. Komitmen organisasi berpengaruh positif dan signifikan terhadap kepuasan kerja karyawan di PT. Pertamina RU IV (Persero) Cilacap dengan dimediasi oleh motivasi kerja sebesar 0,255. Komitmen organisasi yang tinggi tanpa meningkatkan motivasi kerja tidak dapat menjamin tingginya kepuasan kerja, namun tingginya komitmen organisasi diikuti dengan tingginya motivasi kerja mampu meningkatkan kepuasan kerja.

2. Karakteristik pekerjaan berpengaruh positif sebesar 0,235 dan signifikan terhadap kepuasan kerja. Pengaruh tersebut langsung tanpa harus dimediasi oleh motivasi kerja.

3. Komitmen organisasi berpengaruh positif sebesar 4,913 terhadap motivasi kerja. Semakin tinggi komitmen organisasi karyawan maka semakin tinggi motivasi kerjanya.

4. Karakteristik pekerjaan berpengaruh positif sebesar 3,461 dan signifikan terhadap motivasi kerja. Semakin tinggi karakteristik pekerjaan, maka semakin 
tinggi motivasi kerja karyawan di PT. Pertamina RU IV (Persero) Cilacap.

5. Motivasi kerja berpengaruh positif sebesar 10,086 dan signifikan terhadap kepuasan kerja. Semakin tinggi motivasi kerja, maka semakin tinggi kepuasan kerja karyawan di PT. Pertamina RU IV (Persero) Cilacap.

\section{IMPLIKASI PENELITIAN}

Hasil penelitian menjadi referensi bagi perusahaan PT. Pertamina RU IV (Persero) Cilacap dalam memperhatikan faktor-faktor apa saja yang mempengaruhi kepuasan kerja karyawan yang diantaranya meliputi komitmen organisasi, karakteristik pekerjaan, dan motivasi kerja guna mencapai tujuan sesuai dengan visi misi perusahaan.

Peneliti selanjutnya diharapkan dapat meneliti variabel-variabel lain yang dapat memberikan pengaruh lebih besar terhadap kepuasan kerja karyawan sehingga dapat memperkaya dan memperluas kajian ilmu pengetahuan Sumber Daya Manusia.

\section{DAFTAR PUSTAKA}

Ahmad A. Al-Tit \& Taghrid S. Suifan. (2015). The Mediating Role of Job Characteristics in the Relationship between Organizational Commitment and Job Satisfaction. International Journal of Business and Management, Vol 10 (9), 215-222.

Anoraga, Pandji. (2010). Manajemen Bisnis. Jakarta:Rineka Cipta, Edisi Kedua.

Franciscus, Utomo. (2013). Pengaruh Karaktersistik Pekerjaan dan Kepuasan kerja terhadap Organizational Citizenship Behavior, Pada Karyawan. Jurnal Profit, Vol. 2 (1).

Juliansyah Noor, (2013). Penelitian Ilmu Manajemen, Tinjauan Filosofis dan Praktis. Jakarta:Kencana, Cetakan ke-1.

Ghozali, Imam. 2016. Aplikasi Analisis Multivariete Dengan Program IBM SPSS 23 (Edisi 8). Cetakan ke VIII. Semarang : Badan Penerbit Universitas Diponegoro.

Gibson, et.al. (2012). Organization Behaviour, Structure, Processes. 14th Edition. New York: McGraw-Hill Companies, Inc.

Hackman dan Oldham. (2010). Motivation Through The Design of Work: Test of a Theory, Organizational Behavior and Human Performance. Addision Wesley Publishing Co., Inc.

Luthans, Fred. (2011). Organizational Behavior: An Evidence-Based Approach. New York: McGraw-Hill

Mathis, R.L dan Jackson. (2011). Human Resource Management. Jakarta: Salemba Empat.

Allen dan Meyer. (2013). The Measurement and Antecedents of Affective, Contintinuance and Normative Commitment to Organitazion. Jakarta:PT Elex Media Komputindo.

Munandar. (2014). Psikologi Kepribadian. Jakarta:PT. Raja Grafindo Persada. 
Robbins, P. S., \& Judge, A. T. (2013). Organizational Behavior (15th Ed.). New Jersey: Pearson Prentice Hall.

Spector, P.E. and Fox, S. (2010). Counterproductive Work Behavior and Organizational Citizenship Behavior: Are They Opposite Forms of Active Behavior? Applied Psychology: An International Review, 59, 21-39.

Steers, Richard M. 2011. Efektifitas Organisasi. Jakarta: Erlangga.

Sugiyono. (2018). Metode Penelitian Kuantitatif, Kualitatif, dan R\&D. Bandung: Alfabeta.

Thomas, Adrian., Buboltz, Walter C., Winkelspecht., Christopher S. Organizational Analysis. (2004) 12, 2; ProQuest Health Management pg. 205.

Wijono, Sutarto. (2010). Psikologi Industri \& Organisasi. Jakarta: Fajar Interpratama Offset.

Yucel, Ilhami. (2012). Examining the Relationships among Job Satisfaction, Organizational Commitment, and Turnover Intention: An Empirical Study. International Journal of Business and Management, Vol. 7. No. 20, 44-58. 